\title{
The effect of polyunsaturated fatty acids (PUFA) and organic labeling on Swiss consumers' acceptance of pork salami
}

\author{
Claudia Meier ${ }^{(D)}$ Eugenia Harms $\cdot$ Barbara Früh $\cdot$ Helena Stoffers • \\ Giuseppe Bee $\cdot$ Diana Hartig Hugelshofer $\cdot$ Nele Quander-Stoll $\cdot$ Hanna Stolz
}

Received: 25 September 2020 / Accepted: 3 August 2021 / Published online: 16 September 2021

(C) The Author(s) 2021, corrected publication 2022

\begin{abstract}
Pork salami with a high content of polyunsaturated fatty acids (PUFA) may be unappealing for consumers as it is more prone to the development of off-flavors and a "greasy" texture. In Switzerland, a share of more than $15.5 \%$ PUFA in back fat is penalized with a payment deduction of minimally CHF 0.10 per kilogram carcass weight. In this study, we aimed to assess the effect of different PUFA levels and organic labeling on Swiss consumers' acceptance of pork salami. We conducted a sensory consumer experiment, following a two-factorial treatment structure, crossing the factor "PUFA level" (15.4\% PUFA in back fat vs. $18.3 \%$ PUFA in back fat) and the factor "information on production system" (blind vs. non-organic vs. organic). Consumer acceptance was captured using a 9-point hedonic scale for overall liking and
\end{abstract}

C. Meier $(\bowtie) \cdot$ B. Früh $\cdot$ N. Quander-Stoll $\cdot$ H. Stolz

Research Institute of Organic Agriculture (FiBL),

Ackerstrasse 113, 5070 Frick, Switzerland

e-mail: claudia.meier@fibl.org

E. Harms · D. H. Hugelshofer

School of Agricultural, Forest and Food Sciences (HAFL),

Länggasse 85, 3052 Zollikofen, Switzerland

H. Stoffers

Agroscope, Schwarzenburgstrasse 161, 3097 Liebefeld,

Switzerland

G. Bee

Agroscope, Rte de la Tioleyre 4, 1725 Posieux,

Switzerland an open-ended willingness to pay question. Furthermore, participants had the opportunity to comment on their sensory experience for each product in an open text question. An increased PUFA content in back fat of $18.3 \%$ vs. $15.4 \%$ did not lead to a significant difference in consumer acceptance of pork salami in either of the three information conditions, even though, as identified in the analysis of open comments, the high-PUFA salami tended to be more often perceived as "softer" and/or "more greasy". In contrast, consumer acceptance of both the highand low-PUFA salami was significantly higher under the "organic" than under either the "nonorganic" or blind tasting conditions. Based on this study, a PUFA content in back fat of up to $18 \%$ is not expected to have a negative impact on consumer acceptance of pork salami. Therefore, and based on previous findings, we recommend to adapt the Swiss pork fat quality grading system to account for this higher acceptable PUFA limit of $18 \%$. Future research should further explore trade-offs between sensory quality, sustainability, and healthiness while taking consumers' heterogeneity into account.

Keywords Consumer acceptance · Pork salami . PUFA levels · Organic production · Sensory quality 


\section{Introduction}

Various attributes of fresh pork meat are decisive for its suitability for technological processing and storage (Rosenvold \& Andersen 2003). One attribute that has been of particular interest to the processing and retail industry is the fatty acid composition of adipose tissue and muscle (Rosenvold \& Andersen 2003). A high level of polyunsaturated fatty acids (PUFA) may lead to a reduction in fat firmness; hindering the processing of meat products, such as salami. Furthermore, the risk of accelerated lipid oxidation during processing, storage, and retail display may increase, resulting in elevated levels of sensory rancidity and a reduction in shelf life. Mincing, heating, and freezing increase oxidative stress (Gläser et al. 2002; Wenk et al. 1990; Wood et al. 2008 2003). Therefore, meat with high levels of PUFA is regarded as being of inferior quality from a technological perspective (Rosenvold \& Andersen 2003; Wood et al. 2008 2003). In Switzerland, the amount of PUFA in back fat has been used as the basis for determining pork fat quality since 2014 (Müller \& Scheeder 2014; Proviande 2014). A share of more than $15.5 \%$ PUFA in back fat is penalized with a payment deduction of minimally CHF 0.10 per kilogram carcass weight. If the share exceeds $16.5 \%$, the deduction increases to CHF 0.40 and with a share exceeding $17.5 \%$, the deduction reaches a maximum of CHF 1.00 per kilogram carcass weight.

These limits pose great challenges for organic pork producers. It has been well established that the level of PUFA in pigs' adipose tissue and muscle is directly linked to the level of PUFA in the pigs' diet (Aaslyng \& Meinert 2017; Alonso et al. 2010; Kouba et al. 2003; Rosenvold \& Andersen 2003; Scheeder et al. 1998; Stoll 2004; Wood 1984; Wood et al. 2008). Thus, pork producers are able to control the proportion of PUFA in tissues through the pigs' feed. However, organic producers' flexibility in terms of possible pig feeding strategies is restricted due to the limited availability of low-PUFA feed ingredients and the ban on synthetic amino acids (Leiber \& Früh 2014; Schumacher et al. 2011; Witten et al. 2014). Specifically, potato protein - a feed component that is commonly used in the feeding of pigs due to its excellent amino acid profile and low-PUFA levels - is not available in organic quality, and there is no comparable organic alternative. Several studies have shown that potential alternative sources of protein, such as press cake from oilseeds (Schöne et al. 2002) or extruded soy beans (Van Lunen et al. 2003), elevate the overall PUFA level of the diets and ultimately that of the back fat. As a consequence, PUFA levels of organic pork from $100 \%$ organically fed pigs tend to be higher than PUFA levels of conventionally produced pork (Früh 2016). In Switzerland, organic pork producers are therefore temporarily allowed to use a maximum of $5 \%$ of conventional potato protein in the feed of their pigs (EAER Ordinance on Organic Farming 2020). The associated transitional regulation, which applies until the 31st of December 2022, is only a temporary solution until adequate protein feed sources are available in organic quality.

In addition to processing, the maintenance of a high level of consumer acceptance is an important reason for the implementation of the Swiss PUFA limits (Müller \& Scheeder 2014). Flavor and texture are among the three most important sensory characteristics determining consumer acceptance of highly processed pork products that contain a considerable amount of back fat, such as salami (Iaccarino et al. 2006). Particularly in the case of these products, an elevated level of PUFA may be problematic for consumer acceptance because it can lead to the development of off-flavors and a "greasy" texture (Houben \& Krol 1980; Wood et al. 2008). Scheeder and Müller (2014) reported that PUFA contents in back fat above $18 \%$ may lead to problems with consumer acceptance of highly processed, highfat pork products. An earlier study by Warnants et al. (1998) found that a content exceeding 23\% PUFA in back fat may lead to undesirable changes in the flavor of salami if linoleic acid is the predominant PUFA. As in Scheeder and Müller (2014), they suggested a lower limit if linolenic acid is the predominant PUFA because linolenic acid is much more prone to oxidation than linoleic acid (Ahn et al. 1996). Furthermore, Warnants et al. (1998) and Hadorn et al. (2008) each observed a softer consistency in their salamis produced with back fat containing more than 14\% PUFA, but neither of these studies found a relationship between consistency and sensory acceptance.

However, apart from intrinsic product properties, consumers' evaluation of sensory quality, and thus their acceptance, is also strongly influenced by 
existing expectations (Grunert et al. 2004; Lange et al. 2000 1998). Consumer expectations towards the sensory quality of organic food are typically higher than for conventionally produced food, which may lead to a positive, so-called "organic halo" effect on consumer acceptance (Apaolaza et al. 2017; Hemmerling et al. 2013; Napolitano et al. 2010 2013; Scholderer et al. 2004). Furthermore, consumers are heterogeneous in their product quality perception, reflecting differences in cultural backgrounds, eating habits, or sociodemographic characteristics (Combris et al. 2009; Mueller \& Szolnoki 2010; Teuber et al. 2016). For instance, a study by Bryhni et al. (2003) showed that consumers' mean scores for overall liking of cooked pork, including in the presence of offflavors, rose with increasing meat consumption.

In this study, we aimed to assess the effect of different PUFA levels and organic labeling on Swiss consumers' acceptance of pork salami. To our knowledge, this is the first study that examined the effect of different PUFA levels on consumer acceptance in the organic context. We focused on salami, as elevated PUFA levels have been shown to be more problematic in the case of highly processed, high-fat pork products. Furthermore, salami is a very popular high-fat pork sausage among Swiss consumers. In 2019, the Swiss retail industry sold a total of $475 \mathrm{t}$ of pork salami and only $266 \mathrm{t}$ of pork chorizo and $105 \mathrm{t}$ of pork salametti (Proviande 2020).

This consumer study was part of the "Bioschwein 100.0 " project, which tested the influence of $100 \%$ organic feed on fat quality. Thus, the salami that was used for consumer tasting resulted from two dietary treatments of one of the project's feeding trials. One treatment led to $15.4 \%$ PUFA in back fat, resulting in a "low-PUFA" salami, while the other treatment led to 18.3\% PUFA in back fat, resulting in a "high-PUFA" salami. For the remainder of this article, pork salami from back fat with $15.4 \%$ PUFA will be referred to as "PUFA 15.4 salami" or "low-PUFA salami" and pork salami from back fat with $18.3 \%$ PUFA will be referred to as "PUFA 18.3 salami" or "high-PUFA salami". For both the low- and high-PUFA salami, the Thiobarbituric Acid Reactive Substance (TBARS ${ }^{1}$ ) value was

\footnotetext{
${ }^{1}$ Short for thiobarbituric acid reactive substance: TBARS are a widely used indicator for oxidative stress which manifests itself through elevated levels of rancidity (Kim 2014). TBARS are measured in $\mathrm{mg} \mathrm{MDA} / \mathrm{kg}$ in fresh product.
}

recorded upon maturation - shortly before the consumer experiment took place - and did not exceed the critical value of 0.5 . Hence, adverse effects on consumer acceptance due to elevated levels of rancidity were very unlikely with these products.

Hence, based on these framework conditions, the research questions of this study were specified as follows:

(1) Does Swiss consumers' acceptance of pork salami differ between pork salami produced with back fat containing either $18.3 \%$ or $15.4 \%$ PUFA? - PUFA level effect

(2) Is Swiss consumers' acceptance of pork salami influenced by information about the production system? - Organic labeling effect

(3) Is there a relationship between PUFA level and information about the production system? Interaction effect

\section{Materials and methods}

To answer the research questions of this study, we conducted a sensory consumer experiment, following a two-factorial treatment structure, crossing the factor "PUFA level", with two levels (15.4\% PUFA and $18.3 \%$ PUFA) and the factor "information about production system", with three levels (blind, nonorganic, organic). Hence, each consumer tasted both the low- and the high-PUFA salami three times: once blind, once with the claim "organic", and once with the claim "non-organic" in a total of six tasting rounds. Consumer acceptance was captured using a nine point hedonic scale for overall liking (Lim 2011; Peryam \& Pilgrim 1957; Resurreccion 1998), followed by an open-ended willingness to pay question (Lusk \& Hudson 2004).

The combination of sensory and economic scales to measure consumer acceptance is very common: particularly in studies examining the effect of extrinsic quality cues, such as the organic label (Asioli et al. 2017; Combris et al. 2009). In fact, Lange et al. (2002) suggest that, in the presence of external information, hedonic measures may be used to assess the sensory value of the product information and 
Table 1 Analyzed nutrient and energy content (expressed by $\mathrm{kg}$ feed) of the grower and finisher diets

\begin{tabular}{|c|c|c|c|c|}
\hline \multirow[t]{2}{*}{ Items } & \multicolumn{2}{|c|}{ Grower diet } & \multicolumn{2}{|c|}{ Finisher diet } \\
\hline & T1 & $\mathbf{T 2}$ & $\mathbf{T 1}$ & $\mathbf{T 2}$ \\
\hline Dry matter, $\mathrm{g}$ & 889.8 & 888.7 & 882.6 & 892.5 \\
\hline Crude ash, g & 56.3 & 56.9 & 52.8 & 54.2 \\
\hline Crude fiber, $g$ & 42.1 & 69.7 & 37.0 & 71.0 \\
\hline Crude protein, $\mathrm{g}$ & 177.8 & 168.0 & 163.4 & 141.2 \\
\hline Lysine, $g$ & 10.0 & 9.7 & 7.7 & 7.1 \\
\hline Methionine, $\mathrm{g}$ & 3.0 & 2.0 & 2.6 & 2.2 \\
\hline Cystein, $\mathrm{g}$ & 3.5 & 2.8 & 3.1 & 2.9 \\
\hline Crude fat, $g$ & 36.7 & 37.2 & 26.9 & 42.8 \\
\hline SFA, g & 7.7 & 6.4 & 5.5 & 6.7 \\
\hline MUFA, $\mathrm{g}$ & 10.5 & 13.0 & 6.4 & 20.2 \\
\hline PUFA, g & 21.1 & 20.8 & 12.4 & 17.4 \\
\hline PUI, $g^{1}$ & 5.0 & 6.5 & 2.7 & 9.3 \\
\hline IVI, $g^{2}$ & 7.5 & 10.4 & 3.8 & 15.4 \\
\hline Digestible energy, MJ & 13.2 & 12.8 & 13.2 & 12.8 \\
\hline
\end{tabular}

${ }^{1}$ PUI $\quad$ (PUFA-Index): $-0.300 \times \mathrm{SFA}+0.457 \times \mathrm{MUFA}+0.119$ $\times$ PUFA (contents of the fatty acids are expressed as $\mathrm{g} / \mathrm{kg}$ of feed)

${ }^{2}$ IVI (Iodine Value Index): $-0.743 \times \mathrm{SAT}+0.829 \times \mathrm{MUFA}+0$. $212 \times$ PUFA (contents of the fatty acids are expressed as $\mathrm{g} / \mathrm{kg}$ of feed)

willingness to pay to assess the perceived (or total) value of the product information.

\section{Diets and feeding}

The salami that was used for consumer tasting resulted from two, of a total of four, dietary treatments of a feeding trial which was conducted within the "Bioschwein 100.0" project. ${ }^{2}$ For the trial a hundred and forty-four Swiss Large White female $(n=64)$ and castrated $(n=80)$ pigs, originating from thirty-six litters and weighing $24.3 \pm 0.33 \mathrm{~kg}$ (average \pm standard error), were assigned within litter to four dietary treatments. The two treatments that led to the low- and high-PUFA salami are hereafter referred to as treatment one (T1) and treatment two (T2) respectively.

\footnotetext{
2 The Swiss Federal Committee for Animal Care and Use approved all the procedures involving animals (no. 2018_20_ FR-30,297).
}

The nutrient content of the two dietary treatments is shown in Table 1. For T1, which led to the low-PUFA salami, a grower and finisher diet was formulated based on the Swiss feeding recommendations for swine (Agroscope 2016) and following the recommendation that $95 \%$ of the feed ingredients comply with the EAER Ordinance on Organic Farming (2020). For T2, which led to the high-PUFA salami, the feed ingredients used for feed formulation also had to comply with the aforementioned regulation. In order to be isonitrogenous to the $\mathrm{T} 1$ diet, the level of essential amino acid of the T2 diet was 3\% below the Swiss feeding recommendations for swine (Agroscope 2016). A further prerequisite for the formulation of the $\mathrm{T} 2$ diets was to elevate the crude fiber content by $3 \%$ compared to the $\mathrm{T} 1$ diets. Regarding the fatty acid profile, all diets were formulated to comply with the feeding recommendations regarding back fat quality that is a PUFA-Index (PUI) $<5.1 \mathrm{~g} / \mathrm{kg}$ feed and Iodine Value Index (IVI) $<7.8 \mathrm{~g} / \mathrm{kg}$ feed (Stoll 2016). With the imposed restrictions, the PUI and IVI limits were not met for the $\mathrm{T} 2$ diets.

The pigs were reared in group pens $(n=17$ per pen), equipped with automatic feeders and individual pig recognition system (Schauer Maschinenfabrik GmbH \& Co. KG, Prambachkirchen, Austria) that allowed daily feed intake to be recorded. The pigs had ad libitum access to the diets and water. Pigs were changed from the grower to the finisher diet when the body weight $(\mathrm{BW})$ at the day of weighing was greater than $60 \mathrm{~kg}$. Pigs were slaughtered the day after reaching $103 \mathrm{~kg} \mathrm{BW}$ at the research abattoir of Agroscope after being fasted for approximately $12 \mathrm{~h}$. Live BW was determined prior to slaughter. A detailed description of the slaughter procedure is given by Bee et al. (2017). Weights of hot carcasses were assessed 30 min after exsanguination and the carcasses were then chilled at $2{ }^{\circ} \mathrm{C}$ for $24 \mathrm{~h}$. One day post mortem, meat and adipose tissue for the Salami production was collected. The adipose tissue from each right carcass side was excised a the 10th rib level, freed from the skin and muscle, vacuumpacked in opaque bags and stored at $-20{ }^{\circ} \mathrm{C}$ until analysis. From these samples the dry matter, total fat and fatty acid contents were measured by near infrared spectroscopy (NIR) as previously described (Bee et al. 2021) (Table 2). 
Table 2 Fatty acid composition of adipose tissue ( $\mathrm{g} / \mathrm{kg}$ tissue) of female and castrated pigs fed two different grower and finisher diets

\begin{tabular}{lll}
\hline & T1 & T2 \\
\hline Total fat & $863 \pm 31.3$ & $879 \pm 39.9$ \\
SFA & $36.9 \pm 2.46$ & $33.6 \pm 2.88$ \\
MUFA & $47.4 \pm 1.28$ & $48.1 \pm 1.55$ \\
PUFA & $15.4 \pm 1.12$ & $18.3 \pm 1.77$ \\
Iodine value $^{1}$ & $69.3 \pm 3.79$ & $74.9 \pm 4.91$ \\
\hline
\end{tabular}

Measures were taken from the inner and outer back fat layer of each individual carcass. Values represent the average \pm standard deviation of measurements obtained from carcasses from 16 female and 20 castrated pigs per treatment

\section{Preparation of sausages}

Two batches of salami with different lard characteristics (PUFA 15.4 and PUFA 18.3) were produced at the Swiss Butchers Training Center (Ausbildungszentrum der Schweizer Fleischwirtschaft, CH-3700 Spiez). The batches only differed with respect to their PUFA levels. Well-trimmed beef (15\%) was ground to $3 \mathrm{~mm}$ in a mincer (Seydelmann WD 114, 70,174 Stuttgart, Germany). Well-trimmed pork (65\%), lard (20\%), and chopped beef were minced together to $6 \mathrm{~mm}$. The mixture was blended with organic raw sausage spice mixture (12 g/kg), Bio Garlic granulate $(1 \mathrm{~g} / \mathrm{kg}$ ) (both products from Omya $\mathrm{CH}-4710$ Balsthal) and $5 \mathrm{~g}$ AVO Starter culture for raw sausages (AVO-Werke August Beisse GmbH, D$49,187 \mathrm{Belm}$ ) in a bowl cutter using reverse gear of cutter knives (Kutter, K40 AC8, Nr. 16,581-1, Seydelmann, D-73431 Aalen, Germany) for $200 \mathrm{~s}$.
After addition of salt $(6 \mathrm{~g} / \mathrm{kg})$ and curing salt $(16 \mathrm{~g} / \mathrm{kg})$, the mixture was blended until reaching a sufficient binding of the sausage meat. The final mixture was stuffed in collagen casings (R2L-D, Viscofan, D-69469 Weinheim) with a diameter of $50 \mathrm{~mm}$ using a vacuum filler (VF 608 PLUS, Maschinenfabrik, GmbH \& Co. KG, 88,400 Biberach, Germany). The sausages were dipped in a mold/surface solution (scheid-Salamischimmel weiss, scheid-rusal PVH AG, CH-6038 Gisikon) and ripened in a small chamber (size $1.41 \mathrm{~m}^{3}$, own construction Agroscope) with automated temperature and humidity regulation, starting at $24{ }^{\circ} \mathrm{C}$ and $97 \%$ relative humidity with an even lowering to $15{ }^{\circ} \mathrm{C}$ and $72 \%$ relative humidity after 12 days. The ripening was stopped after 28 days when the Salamis reached a weight loss of $35 \%$. The salami was then stored for 2 to 3 weeks at $5{ }^{\circ} \mathrm{C}$ in the dark, wrapped in absorbent paper in a box covered with plastic film until the sensory consumer experiment was conducted.

Table 3 shows the composition and characteristics of the two final salami products that were used for sensory testing.

\section{Recruitment of participants}

Study participants were recruited in the region of Bern, Switzerland, from the consumer database of the School of Agriculture, Forest and Food Science (HAFL), where the sensory experiment took place. Participants were informed that they would participate in a study on food consumption involving some tasting, that the study would last about $1 \mathrm{~h}$ and that they would be remunerated with a total of
Table.3 Composition and characteristics of the two final salami products used for sensory testing

\footnotetext{
${ }^{1}$ Thiobarbituric acid reactive substance (TBARS) was measured shortly before the sensory consumer experiment took place
}

\begin{tabular}{llll}
\hline & & PUFA 15.4 & PUFA 18.3 \\
\hline Weight loss after ripening $(n=10)$ & {$[\%]$} & $35.4 \pm 0.2$ & $34.9 \pm 0.2$ \\
Water content $(n=2)$ & {$[\mathrm{g} / \mathrm{kg}]$} & $417 \pm 0.0$ & $408 \pm 1.4$ \\
Warner Bratzler $(n=3)$ & Maximum Force $[\mathrm{N}]$ & $86.4 \pm 12.1$ & $80.2 \pm 19.0$ \\
Water activity $(n=2)$ & {$[-]$} & $0.907 \pm 0.007$ & $0.919 \pm 0.004$ \\
TBARS $^{1}(n=2)$ & mg MDA/kg in fresh product & $0.30 \pm 0.00$ & $0.27 \pm 0.01$ \\
Protein & {$[\%]$ in dry matter } & 46.9 & 46.0 \\
Fat & {$[\%]$ in dry matter } & 44.0 & 45.4 \\
Ash & {$[\%]$ in dry matter } & 9.1 & 8.6 \\
\hline
\end{tabular}


Table 4 Sociodemographic characteristics of the $n=108$ consumers

\begin{tabular}{|c|c|c|c|c|}
\hline & Categories & $n$ & Valid \% & Mean \\
\hline \multirow[t]{2}{*}{ Gender } & Female & 55 & 50.93 & - \\
\hline & Male & 53 & 49.07 & \\
\hline \multirow[t]{4}{*}{ Age in years } & 18 to 29 & 15 & 13.89 & 52.47 \\
\hline & 30 to 44 & 10 & 9.26 & \\
\hline & 45 to 59 & 40 & 37.04 & \\
\hline & 60 to 79 & 43 & 39.81 & \\
\hline \multirow[t]{4}{*}{ Highest educational level } & Low (up to 10 years, pre-vocational training and the like) & 3 & 2.78 & - \\
\hline & $\begin{array}{l}\text { Intermediate (above } 10 \text { years, up to basic vocational training, } \\
\text { Matura) }\end{array}$ & 81 & 75.00 & \\
\hline & High (from bachelor onwards) & 23 & 21.30 & \\
\hline & No answer & 1 & 0.93 & \\
\hline \multirow[t]{3}{*}{ Household size } & $1-2$ person(s) & 73 & 67.59 & 2.46 \\
\hline & $3-4$ persons & 28 & 25.93 & \\
\hline & $>4$ persons & 7 & 6.48 & \\
\hline \multirow[t]{4}{*}{ Monthly household income (CHF) } & Up to 6000 & 26 & 24.07 & - \\
\hline & 6001 to 10,000 & 50 & 46.30 & \\
\hline & Above 10,000 & 16 & 14.81 & \\
\hline & No answer & 16 & 14.81 & \\
\hline \multirow[t]{4}{*}{ Employment } & Fully employed $-90 \%$ or more & 24 & 22.22 & - \\
\hline & Part time -50 to $89 \%$ & 26 & 24.07 & \\
\hline & Part time - below $50 \%$ & 12 & 11.11 & \\
\hline & Not employed & 46 & 42.59 & \\
\hline
\end{tabular}

CHF 25 upon completion of the experiment. ${ }^{3}$ To be eligible for the study, participants had to be at least jointly responsible for food purchase in their household, between 18 and 79 years old, not work in marketing/market research/publishing, food production/processing or retail, not be vegetarian, and be willing to taste pork salami. To ensure a certain degree of heterogeneity in the sample, participants were recruited based on the following quota: gender (50\% women; $50 \%$ men), age (50\% 18 to 44 years; $50 \% 45$ to 79 years), organic consumption frequency (at least $40 \%$ consuming organic food rather often, very often, or (almost) always), and organic meat consumption frequency (at least $40 \%$ consuming organic meat rather often or very often). The final sample size included 108 consumers. The main sociodemographic characteristics are shown in Table 4 and the organic and meat consumption

\footnotetext{
${ }^{3}$ Before the start of the experiment, participants gave their informed consent.
}

frequency in Table 5. The target quota was achieved except for age. Thus, study participants were almost equally distributed for gender and $57 \%$ stated that they consume organic food, and $44 \%$ organic meat, rather often or more frequently. With a share of $23 \%$, participants below the age of 44 were underrepresented in the sample.

Sensory consumer experiment

The sensory consumer experiment took place in the sensory lab of the School of Agriculture, Forest and Food Science (HAFL) in Bern, Switzerland, at the beginning of December 2017. HAFL's sensory lab is designed according to the ISO 8589:2007 standard and comprises 11 booths. To reach the sample size of $n=108$, a total of eleven different sessions were held. The sessions were spread over a period of five days and took place in the morning, afternoon, or evening. Each session lasted about $1 \mathrm{~h}$.

As in Scholderer et al. (2004), the consumer experiment followed a two-way factorial treatment 
Table 5 Eating habits of the $n=108$ consumers

\begin{tabular}{lllll}
\hline & Categories & $\boldsymbol{n}$ & Valid \% & Mean \\
\hline Organic food consumption frequency & (Almost) always (1) & 2 & 1.85 & 3.42 \\
& Very often (2) & 21 & 19.44 & \\
& Rather often (3) & 39 & 36.11 \\
& Occasionally (4) & 32 & 29.63 \\
& Rather rarely (5) & 6 & 5.56 \\
& Very rarely (6) & 6 & 5.56 \\
& (Almost) never (7) & 2 & 1.85 \\
& Very often (1) & 24 & 22.22 & 2.15 \\
& Rather often (2) & 51 & 47.22 & \\
& Occasionally (3) & 29 & 26.85 \\
& Rather rarely (4) & 1 & 0.93 \\
& Very rarely (5) & 3 & 2.78 \\
& (Almost) never (6) & 0 & 0.00 \\
Organic meat consumption frequency & (Almost) always (1) & 4 & 3.70 \\
& Very often (2) & 18 & 16.67 \\
& Rather often (3) & 25 & 23.15 \\
& Occasionally (4) & 32 & 29.63 \\
& Rather rarely (5) & 18 & 16.67 \\
& Very rarely (6) & 6 & 5.56 \\
& (Almost) never (7) & 5 & 4.63 \\
\\
& &
\end{tabular}

Table 6 Experimental design with six treatments

\begin{tabular}{llll}
\hline & No information & Non-organic & Organic \\
\hline PUFA level 15.4 & A [n=108] & C $[n=108]$ & E $[n=108]$ \\
PUFA level 18.3 & B [n=108] & D $[n=108]$ & F $[n=108]$ \\
\hline
\end{tabular}

structure, which is shown in Table 6. The two factors which were crossed were "PUFA level", with two levels ( $15.4 \%$ and $18.3 \%$ PUFA in back fat), and "information about production system", with three levels (no information, non-organic, and organic), resulting in a total of six different treatments or product samples. Each product sample consisted of two salami slices each $1.5 \mathrm{~mm}$ thin, which were cut half an hour before the experiment, marked with a random three-digit code and stored in a fridge at $4.4{ }^{\circ} \mathrm{C}$ until serving. The information about the production system was not attached to the product samples themselves, but directly included in the

Table 7 Procedure of product sample evaluation

\section{Part 1: Overall liking}

Question: How much do you like this (no information/organic/non-organic) salami overall?

Answer: Hedonic scale from 1 (= dislike extremely) to 9 (like extremely)

Part 2: Willingness to pay

2.1: Purchase intent (PI)

Question: Would you buy this (no information/organic/non-organic) salami if you had the opportunity?

Answer: yes or no

2.2: If yes: Maximum willingness to pay

Question: What is the maximum amount you would pay for $200 \mathrm{~g}$ (no information/organic/non-organic) salami if it tasted the same as the salami you just tried? (Note: In a supermarket $200 \mathrm{~g}$ salami $(\mathrm{CH})$ costs, on average, $\mathrm{CHF}$ 5.00)

Answer: Open-end

Part 3: Open text field for comments 
evaluation survey. For instance, before tasting the organic salami consumers received the following information: "Please note that the salami you will now taste is from organic production." After tasting the organic salami, they were explicitly asked about their overall liking/willingness to pay for the tasted "organic" salami (see Table 7). The PUFA level was not communicated to consumers, which is the normal procedure for intrinsic product characteristics (Grunert et al. 2004).

Upon arrival at the sensory lab, participants were asked to take a seat in one of the individual booths and to follow the instructions on the computer screen. During the experiment, each participant (experimental unit) evaluated all six product samples (treatments), one-byone, using a hedonic and an economic measure: a nine point hedonic scale for overall liking and a two-part willingness to pay question, first asking about purchase intent and then about maximum willingness to pay in an open-end format (see Table 7). A similar approach was used in Scholderer et al. (2004) and in Dransfield et al. (2005). For each product sample, respondents also had the opportunity to comment on their experience. Between samples, participants were instructed to rinse their palate with water and/or consume a cracker in order to neutralize their taste buds.

As in other studies examining information effects on consumer acceptance (Combris et al. 2009; Hemmerling et al. 2013; Napolitano et al. 2010; Torquati et al. 2018), the experiment was not completely randomized, in that the order in which treatments were assigned to experimental units was not completely at random (Oehlert 2010). Product samples A and B (no information), $\mathrm{C}$ and $\mathrm{D}$ (non-organic), and $\mathrm{E}$ and $\mathrm{F}$ (organic) were always evaluated in pairs, not simultaneously but one after the other (e.g., BACDFE, ABDCEF, ABEFDC). In addition, product samples A and $\mathrm{B}$ (no information) were always evaluated first as they were used as control treatments (no information provision). Hence, once A and B had been evaluated, either $\mathrm{C}$ and $\mathrm{D}$ or $\mathrm{E}$ and $\mathrm{F}$ followed.

It is also important to note that the total of six product samples came from two different products only - samples A, C, and E from the PUFA 15.4 salami and samples B, D, and F from the PUFA 18.3 salami. That is, samples A, C, and E as well as samples B, $\mathrm{D}$, and $\mathrm{F}$ only differed with respect to the information provided. As consumers were blinded with regard to the PUFA level, they did not know which of the two products they were tasting. Hence, from the participants' perspective they essentially tasted two samples without information, two "organic" samples and two "non-organic" samples.

The provision of "false information" (in this case about the production system) is common practice in experiments aimed at the unbiased measurement of information effects (Scholderer et al. 2004).

\section{Data analysis}

Analysis of overall liking, purchase intent, and willingness to pay

All statistical analyses were performed using $\mathrm{R}$ version 3.6.1 (R Core Team 2019).

To investigate the effect of PUFA level and information on (1) overall liking and (2) willingness to pay, we run two separate linear mixed-effects models, one for each response variable. Mixed-effects models are increasingly used in repeated measures studies where observations are clustered and therefore cannot be considered as independent (Crowder 2017; Cudeck 1996). In this study, we included a random effect on the intercept of each model, allowing subjects to have shifted response levels. Such models are also referred to as random intercept models. To model overall liking we used the following equation:

$$
\begin{gathered}
\left(O L_{i}\right)^{2}=\beta_{0}+\beta_{1} \mathrm{PUFA}_{i}+\beta_{2} \mathrm{INFO}_{i}+\beta_{3} \mathrm{PUFA}_{i} \times \mathrm{INFO}_{i}+u\left(\text { subject }_{i}\right) \\
i=1, \ldots, n \text { for observation } i(n=648) . \\
u\left(\text { subject }_{i}\right) \sim N\left(0, \sigma_{u}^{2}\right)
\end{gathered}
$$

As willingness to pay was measured in two stages, we also modeled it in two stages, following the double-hurdle approach, proposed by Cragg (1971). First, we modeled the probability that someone would be willing to purchase the product, using a two-level random intercept model (the first hurdle):

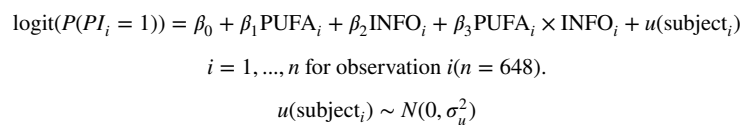

Second, we modeled the maximum amount a participant (with $P I_{i}=1$ ) would be willing to pay for the product, using a linear random intercept model (the second hurdle): 


$$
\begin{gathered}
\mathrm{WTP}_{i}=\beta_{0}+\beta_{1} \mathrm{PUFA}_{i}+\beta_{2} \mathrm{INFO}_{i}+\beta_{3} \mathrm{PUFA}_{i} \times \mathrm{INFO}_{i}+u\left(\text { subject }_{i}\right) \\
i=1, \ldots, n \text { for observation } i(n=385) . \\
u\left(\text { subject }_{i}\right) \sim N\left(0, \sigma_{u}^{2}\right)
\end{gathered}
$$

Each model included two explanatory variables - a factor for PUFA level $\left(P U F A_{i}\right)$, with two possible values, and a factor for information $\left(\mathrm{INFO}_{i}\right)$ with three possible values - and the interaction effect of the two factors. Overall liking was found to be left-skewed and therefore replaced by the square of overall liking. Due to the limited sample size of 108 respondents, no further explanatory variables, such as organic or meat consumption frequency, were included in the model.

In accordance with the research questions stated in the introduction of this article, we tested the following three Null hypotheses in all three models:

(1) PUFA level effect: $H_{0}^{1}: \beta_{1}=0$

(2) Organic labeling effect: $H_{0}^{2}: \beta_{2}=0$

(3) Interaction effect: $H_{0}^{3}: \beta_{3}=0$

The linear random intercept models were estimated using the function lmer from the lme4 package (Bates et al. 2015) and the two-level random intercept model using the function clmm from the ordinal package (Christensen 2015). Contrasts were calculated using the Tukey correction. Effect sizes for overall liking were quantified using the Cohen's $d$ for paired samples $t$-test and effect sizes for willingness to pay $(>0)$ were quantified using the Cohen's $d$ two samples $t$-test.

To measure the influence of overall liking on purchase intent and willingness to pay, we used a simple logistic and linear regression model, respectively, and quantified the effect sizes using Cohen's $d$.

Coding and analysis of open comments

Respondents' open comments, which were obtained by product sample, were analyzed using the software MaxQDA, release 20.0.8 (VERBI Software 2019). Comments were categorized into positive and negative, clearly interpretable denominations with respect to consistency and aroma/taste. Negative comments on a product sample's consistency included the statements "(too) fatty/greasy" and "(too) soft", while positive statements included "good consistency/good bite" and "not greasy/fatty". In the category aroma/ taste, statements such as "well spiced" or "tasty" were evaluated as positive, whereas negative statements included terms such as "rancid", "too little spiced", "too salty", "not tasty" and "special aftertaste".

Due to the qualitative nature of the open comments, they were analyzed using descriptive statistics only.

\section{Results}

The effect of PUFA level and information on overall liking, purchase intent, and willingness to pay

Table 8 summarizes participants' overall liking, purchase intent, and maximum willingness to pay for salami in all six experimental conditions. For overall liking, summary statistics are shown for the total sample as well as by purchase intent.

The results suggest that all six salami samples were acceptable to consumers. Thus, all samples were rated at a mean overall liking score of at least 6 , which is well above the central point of the 9-point hedonic scale. Moreover, in all six experimental conditions more than half of the respondents indicated that they would be willing to buy $200 \mathrm{~g}$ of the tasted salami and would be willing to pay an average of at least $5 \mathrm{CHF}$ for it, which corresponds to the average supermarket price stated in the evaluation survey.

Tables 9, 10, and Table 11 in the Appendix show the results of the random intercept models described in the section "Data analysis".

In all three models, the PUFA level showed no significant effect. Hence, overall liking, purchase intent, and willingness to pay did not significantly differ between the high- and the low-PUFA salami in any of the three information conditions.

The information about the production system had a significant effect on overall liking and willingness to pay, but not on purchase intent. In the case of overall liking, the claim "organic" led to a small increase of $6 \%$, relative to the blind tasting condition (Tukey corrected $p$-value $=0.011$, Cohen's $d=0.22$ ) as well as relative to the "non-organic" information condition (Tukey corrected $p$-value $=0.015$, Cohen's $d=0.25$ ). Between the blind tasting condition and the "non-organic" information condition, 
Table 8 Summary statistics for overall liking, purchase intent, and willingness to pay

\begin{tabular}{|c|c|c|c|c|c|c|}
\hline & \multicolumn{2}{|l|}{ No Info } & \multicolumn{2}{|l|}{ Non-Organic } & \multicolumn{2}{|l|}{ Organic } \\
\hline & PUFA 15.4 [A] & PUFA 18.3 [B] & PUFA $15.4[\mathrm{C}]$ & PUFA 18.3 [D] & PUFA 15.4 [E] & PUFA $18.3[\mathrm{~F}]$ \\
\hline \multicolumn{7}{|c|}{ Overall liking } \\
\hline Mean & 6.1 & 6.3 & 6.2 & 6.2 & 6.7 & 6.5 \\
\hline Std. dev & 1.89 & 1.75 & 1.83 & 1.71 & 1.79 & 1.81 \\
\hline Median & 6.5 & 7.0 & 6.5 & 6.0 & 7.0 & 7.0 \\
\hline$n$ & 108 & 108 & 108 & 108 & 108 & 108 \\
\hline \multicolumn{7}{|c|}{ Purchase intent (PI) } \\
\hline Mean & 0.58 & 0.56 & 0.59 & 0.58 & 0.65 & 0.60 \\
\hline$n$ & 108 & 108 & 108 & 108 & 108 & 108 \\
\hline \multicolumn{7}{|c|}{ Overall liking, PI yes } \\
\hline Mean & 7.2 & 7.3 & 7.2 & 7.1 & 7.5 & 7.4 \\
\hline Std. dev & 1.28 & 1.12 & 1.18 & 1.20 & 1.14 & 1.17 \\
\hline Median & 7.0 & 7.0 & 7.0 & 7.0 & 8.0 & 8.0 \\
\hline$n$ & 63 & 60 & 64 & 63 & 70 & 65 \\
\hline \multicolumn{7}{|c|}{ Overall liking, PI no } \\
\hline Mean & 4.6 & 5.1 & 4.8 & 4.9 & 5.2 & 5.1 \\
\hline Std. dev & 1.54 & 1.62 & 1.67 & 1.53 & 1.83 & 1.74 \\
\hline Median & 5.0 & 5.0 & 5.0 & 5.0 & 5.5 & 5.0 \\
\hline$n$ & 45 & 48 & 44 & 45 & 38 & 43 \\
\hline \multicolumn{7}{|c|}{ Will. to pay, PI yes } \\
\hline Mean & 5.1 & 5.0 & 5.0 & 5.0 & 5.8 & 5.7 \\
\hline Std. dev & 0.91 & 1.01 & 0.91 & 0.98 & 1.05 & 1.16 \\
\hline Median & 5.0 & 5.0 & 5.0 & 5.0 & 5.7 & 5.5 \\
\hline$n$ & 63 & 60 & 64 & 63 & 70 & 65 \\
\hline
\end{tabular}

there was no significant difference in overall liking (Tukey corrected $p$-value $=0.993$, Cohen's $d=0.04$ ). In the case of willingness to pay, the claim "organic" led to a moderate increase of $14 \%$ relative to the blind tasting condition (Tukey corrected $p$-value $<0.001$, Cohen's $d=0.54$ ), and a moderate increase of $15 \%$ relative to the "nonorganic" information condition (Tukey corrected $p$-value $<0.001$, Cohen's $d=0.77$ ). As for overall liking, there was no significant difference in willingness to pay between the blind tasting condition and the "non-organic" information condition (Tukey corrected $p$-value $=0.870$, Cohen's $d=0.16$ ).

Hence, based on these results, there was no PUFA effect, but there was a positive organic labeling effect, which was smaller for overall liking than for willingness to pay. Purchase intent was affected neither by the PUFA level nor by the information on the production system.
Comparison of open comments between different PUFA products and information conditions

In the category consistency, there was a total of 290 comments, of which $62 \%$ were negative, such as "fatty and too soft", and $38 \%$ positive, such as "good consistency/good bite". The share of negative comments was lowest in the "organic" information condition ( $48 \%$ of a total of 99 comments). Furthermore, the share of negative comments tended to be lower for the low-PUFA salami (56\% of a total of 140 comments) than for the highPUFA salami (67\% of a total of 150 comments). In fact, the "organic" low-PUFA salami was the only sample where the positive comments outweighed the negative comments.

In the blind tasting condition, 48 consistency-related comments $(n=47)$ were counted for the low-PUFA salami, whereby $27 \%$ of the comments were positive and $73 \%$ negative. A 
comparable distribution of positive (22\%) and negative (78\%) statements was also found for the high-PUFA salami (blind tasting condition) with a total of 59 comments $(n=53)$. Hence, the perception of the consistency as "fatty" and "(too) soft" appeared to be very similar for both low- and high-PUFA salami. In the "organic" information condition, the distribution was reversed, but only for the low-PUFA salami. Thus, of a total of 50 entries $(n=47), 60 \%$ of the statements were positive, and $40 \%$ negative. Even though, for the high-PUFA salami, the distribution was not reversed in the "organic" information condition, the consistency seems to have been perceived less negatively in comparison with the blind tasting condition. In the "non-organic" information condition, the number of negative consistency-related comments also tended to be lower than in the blind tasting condition, but the negative still outweighed the positive comments in the cases of both low- and high-PUFA salami.

For the aroma/taste-related category, there was a total of 470 comments, of which $50 \%$ were negative, such as "too little spiced", "too salty", or "not tasty" and $50 \%$ positive such as "well spiced" or "good taste". Also across PUFA levels and information conditions, the shares of negative and positive comments were approximately balanced.

Relationship between overall liking, purchase intent, and willingness to pay

The effect of overall liking on purchase intent was found to be highly significant ( $p$-value $<0.001$ ). For a one unit increase in overall liking, the odds of a respondent to be willing to purchase a product were found to increase by $203 \%$ (Cohen's $d=1.63$ ). Whereas the majority of the participants who stated to be willing to purchase a product had an overall liking above 6 , the majority of the participants who stated not to be willing to purchase a product had an overall liking of 6 or below (Fig. 1 in the Appendix).

The effect of overall liking on willingness to pay was also found to be highly significant ( $p$-value $<0.001$ ). For one unit increase in overall liking, willingness to pay was found to increase by CHF 0.32 (Fig. 2 in the Appendix).

\section{Discussion}

An increased PUFA content in back fat of $18.3 \%$ vs. $15.4 \%$ did not lead to a significant difference in consumer acceptance of pork salami in any of the three information conditions, even though the highPUFA salami tended to be more often perceived as "softer" and/or "more greasy". This result supports the proposition of Scheeder and Müller (2014) that a PUFA content in back fat above $18 \%$ may lead to perceptible sensory differences. However, it also suggests that a PUFA content of $18.3 \%$ is still too low and the resulting sensory differences too small to show a negative effect on consumer acceptance. Previous studies have found that only considerably higher contents of PUFA in back fat are problematic for sensory acceptance. In Scheeder et al. (1998) a content of $22.3 \%$ PUFA in back fat led to fishy offflavors and thus had a clear negative effect on consumers' acceptance of bacon, salami, and salametti. In Warnants et al. (1998), contents of 24-27\% PUFA in back fat were problematic for consumers' acceptance of salami due to oilier texture, if linoleic acid was the predominant PUFA, and a fishy taint, if linolenic acid was the predominant PUFA. Bryhni et al. (2002) reported rancid off-flavors and thus lower consumer acceptance of salami for a content of $30.1 \%$ PUFA in back fat. Hence, based on previous consumer studies and the result of the present study, a content of $18 \%$ PUFA in back fat seems to be acceptable from a consumer perspective, particularly if linoleic acid is the predominant PUFA.

Whereas in the present study, consumers' acceptance was not influenced by the PUFA level, it was affected by the claim "organic". The rather small increase in overall liking of about $6 \%$ is in line with the findings of other studies on consumer acceptance of organic meat products. For instance, in Napolitano et al. (2013), occasional organic consumers' overall liking of "organic" chicken increased by $8 \%$ compared to the blind tasting situation. Scholderer et al. (2004) reported an organic labeling effect on overall liking of pork chops of $7 \%$ with respect to the blind tasting condition and $11 \%$ with respect to the "non-organic" information condition. Dransfield et al. (2005) found an increase in overall liking of pork labeled as "outdoor" of up to $6 \%$, compared to the blind tasting condition, and of up to $7 \%$ compared to the "indoor" information condition. Also the moderate increase in willingness to pay of $14 \%$ - compared to the blind tasting condition — and 15\% — compared to the 
"non-organic" information condition - is in accordance with previous studies. In Scholderer et al. (2004), the premium for "organic" pork chops was $12 \%$ compared to the blind condition, and 15\% compared to the "non-organic" information condition. Dransfield et al. (2005) found premiums of up to $8 \%$ and $11 \%$ compared to the blind and "indoor" information condition, respectively. In both these studies, willingness to pay was also elicited using an openended format maximum willingness to pay question. Hence, using the example of pork salami, this study confirms that the claim "organic" has a positive influence on the perceived quality of organic food due to higher consumer expectations.

In line with the studies by Scholderer et al. (2004) and Dransfield et al. (2005), this study showed that the claim "organic" tended to have a larger influence on willingness to pay than on overall liking. In addition, in line with Hung and Verbeke (2018), we found the effect of overall liking on purchase intent and willingness to pay to be highly significant. These findings suggest that the perceived (total) value of the information "organic", as it was measured by consumers' willingness to pay, was attributable to the good sensory quality image of organic food (Baranek 2007; Hemmerling et al. 2013; Kuhnert et al. 2003; Plaßmann \& Hamm 2009) but also to other factors, such as ethical or health concerns (Grunert et al. 2004; Stolz et al. 2009 2011).

The present study also faces some limitations. First of all, storage time of salami was not included as another varying factor in this study. As the oxidative stability of PUFA decreases with increasing storage time, it might be that a longer storage time would have led to detectable off-flavors for consumers and consequently a lower acceptance of the high-PUFA salami (Houben \& Krol 1980; Kerth et al. 2015). Nevertheless, the storage time that was chosen for this study corresponds to a usual storage time. Secondly, the present study only analyzed two specific PUFA levels so the results can therefore not be generalized for PUFA levels which fall outside this range. Thirdly, results were obtained in a sensory lab environment. Some studies have shown that consumers' evaluation of product quality can be significantly affected by the setting in which products were tasted and rated (Boutrolle et al. 2005; Brewer et al. 2001). For instance, in the studies by Boutrolle et al. (2005) and Brewer et al. (2001) the liking scores were lower with central location testing than home-use testing. In contrast, other studies have shown that results are not necessarily dependent on the test setting (Schouteten et al. 2019). Finally, as the study context was hypothetical and consumers did not actually buy any products, the measurements obtained for overall liking, purchase intent, and willingness to pay may not reflect consumers' real buying behavior. In real life, consumers face economic constraints which significantly affect their purchase decisions (Lange et al. 1998).

Future research should further explore trade-offs between sensory quality, sustainability, and healthiness and also take consumers' heterogeneity into account. Ultimately, it is consumers' acceptance of a meat product which determines its success on the market (Moskowitz 1985) and consumers' acceptance is not only influenced by sensory quality but also consumers ethical and health concerns (Moloney et al. 2001; Casal et al. 2018; Soladoye et al. 2015; Teuber 2016; Bryhni 2002). This is relevant in the discussion about PUFA limits as PUFA levels in the back fat of pigs tend to be higher in the context of organic production (Früh 2016) and as a higher level of PUFA also seems to be advantageous from a health perspective (Moloney et al. 2001; Verbeke et al. 1999; Stewart et al. 2001 in Van Lunen et al. 2003; Alonso 2010; Wang et al. 2017).

\section{Conclusion}

In this study, an increased PUFA content in back fat of $18.3 \%$ vs. $15.4 \%$ did not lead to a significant difference in consumer acceptance of pork salami: neither when blindly tasted nor when claimed "organic" or "nonorganic". This suggests that a PUFA limit of $18 \%$ is sufficiently low to ensure a high consumer acceptance: particularly also of organic meat products for which consumer expectations towards taste are typically higher. This is an important finding for Swiss producers and processors of organic pork who suffer from the current Swiss PUFA limits for pork fat quality as the feeding strategies in organic production systematically lead to higher PUFA levels. Based on this study and the evidence provided by previous studies we recommend to adapt the Swiss feeding strategy to account for this higher acceptable PUFA limit of $18 \%$. 
Acknowledgements The authors are grateful to Dr. sc. nat. Robert Home from the Research Institute of Organic Agriculture (FiBL) for proof reading the article and to Jérémy Hentgen for his advice on the statistical analysis.

Author contributions All authors contributed to the study conception and design. Material preparation, data collection, and analysis were performed by $\mathrm{CM}, \mathrm{EH}$, and $\mathrm{DHH}$. The first draft of the manuscript was written by $\mathrm{CM}$ and $\mathrm{EH}$ and all authors commented on previous versions of the manuscript. All authors read and approved the final manuscript.

Funding Open Access funding provided by Forschungsinstitut für biologischen Landbau (FiBL). This work was supported by the Swiss Department of Agriculture.
Data availability The data are available on request from the authors.

\section{Declarations}

Conflict of interest This manuscript has not been submitted to, nor is under review at, another journal or other publishing venue. The following authors have affiliations with organizations with direct or indirect financial interest in the subject matter discussed in the manuscript: Authors' name Affiliation Claudia Meier: None Eugenia Harms: None Barbara Früh: None Helena Stoffers: None Giuseppe Bee: None Diana Hartig Hugelshofer: None Nele Quander-Stoll: None Hanna Stolz: None

\section{Appendix}

Table 9 The effect of PUFA level and information on overall liking (linear random intercept model)

\begin{tabular}{|c|c|c|c|c|c|}
\hline Variable & Coefficient & $\begin{array}{l}\text { Lower } \\
\text { bound } \\
(2.5 \%)\end{array}$ & $\begin{array}{l}\text { Upper } \\
\text { bound } \\
(97.5 \%)\end{array}$ & Std. Error & $p$-value \\
\hline PUFA $18.3($ ref = PUFA 15.4$)$ & 1.69 & -2.61 & 6.00 & 2.20 & 0.442 \\
\hline NOT ORGANIC (ref=BLIND) & 0.24 & -4.07 & 4.55 & 2.20 & 0.913 \\
\hline ORGANIC (ref= BLIND) & $6.38 * *$ & 2.07 & 10.69 & 2.20 & 0.004 \\
\hline PUFA $18.3 \times$ NOT ORGANIC & -2.46 & -8.55 & 3.63 & 3.12 & 0.430 \\
\hline PUFA $18.3 \times$ ORGANIC & -3.70 & -9.80 & 2.39 & 3.12 & 0.235 \\
\hline Constant & $41.23 * * *$ & 37.26 & 45.20 & 2.03 & 0.000 \\
\hline Individual variance & 182.6 & & & & \\
\hline Residual variance & 262.3 & & & & \\
\hline $\begin{array}{l}\text { Rho (individual variance as frac- } \\
\text { tion of total) }\end{array}$ & 0.41 & & & & \\
\hline Marginal/conditional $R^{2}$ & $0.01 / 0.42$ & & & & \\
\hline AIC & 5618 & & & & \\
\hline$n$ & $108 \times 6=648$ & & & & \\
\hline
\end{tabular}


Table 10 The effect of PUFA level and information on purchase intent (twolevel random intercept model)

Table 11 The effect of PUFA level and information on maximum willingness to pay (linear random intercept model)

\begin{tabular}{llllll}
\hline Variable & Coefficient & $\begin{array}{l}\text { Lower } \\
\text { bound } \\
(2.5 \%)\end{array}$ & $\begin{array}{l}\text { Upper } \\
\text { bound } \\
(97.5 \%)\end{array}$ & Std. Error & $p$-value \\
\hline PUFA 18.3 (ref=PUFA 15.4) & -0.14 & -0.74 & 0.46 & 0.31 & 0.650 \\
NOT ORGANIC (ref=BLIND) & 0.05 & -0.55 & 0.65 & 0.31 & 0.880 \\
ORGANIC (ref=BLIND) & 0.34 & -0.27 & 0.95 & 0.31 & 0.280 \\
PUFA 18.3× NOT ORGANIC & 0.09 & -0.76 & 0.94 & 0.43 & 0.830 \\
PUFA 18.3×ORGANIC & -0.10 & -0.96 & 0.75 & 0.44 & 0.810 \\
Constant & -0.41 & -0.88 & 0.06 & 0.24 & NA \\
Individual variance & 1.16 & & & & \\
Residual variance & 3.29 & & & & \\
Rho (individual variance as frac- & 0.26 & & & & \\
$\quad$ tion of total) & $\mathrm{NA}$ & & & & \\
Marginal/conditional $R^{2}$ & 848 & & & & \\
AIC & $108 \times 6=648$ & & & & \\
$n$ &
\end{tabular}

\begin{tabular}{|c|c|c|c|c|c|}
\hline Variable & Coefficient & $\begin{array}{l}\text { Lower } \\
\text { bound } \\
(2.5 \%)\end{array}$ & $\begin{array}{l}\text { Upper } \\
\text { bound } \\
(97.5 \%)\end{array}$ & Std. Error & $p$-value \\
\hline PUFA $18.3(\mathrm{ref}=$ PUFA 15.4$)$ & 0.03 & -0.19 & 0.24 & 0.11 & 0.820 \\
\hline NOT ORGANIC (ref=BLIND) & -0.06 & -0.27 & 0.16 & 0.11 & 0.610 \\
\hline ORGANIC (ref= BLIND) & $0.50 * * *$ & 0.29 & 0.71 & 0.11 & 0.000 \\
\hline PUFA $18.3 \times$ NOT ORGANIC & -0.17 & -0.48 & 0.13 & 0.16 & 0.270 \\
\hline PUFA $18.3 \times$ ORGANIC & -0.07 & -0.37 & 0.24 & 0.16 & 0.660 \\
\hline Constant & $5.09 * * *$ & 4.90 & 5.28 & 0.10 & 0.000 \\
\hline Individual variance & 0.358 & & & & \\
\hline Residual variance & 0.347 & & & & \\
\hline $\begin{array}{l}\text { Rho (individual variance as frac- } \\
\text { tion of total) }\end{array}$ & 0.51 & & & & \\
\hline Marginal/conditional $R^{2}$ & $0.09 / 0.55$ & & & & \\
\hline AIC & 839 & & & & \\
\hline $\mathrm{N}$ & 385 & & & & \\
\hline
\end{tabular}



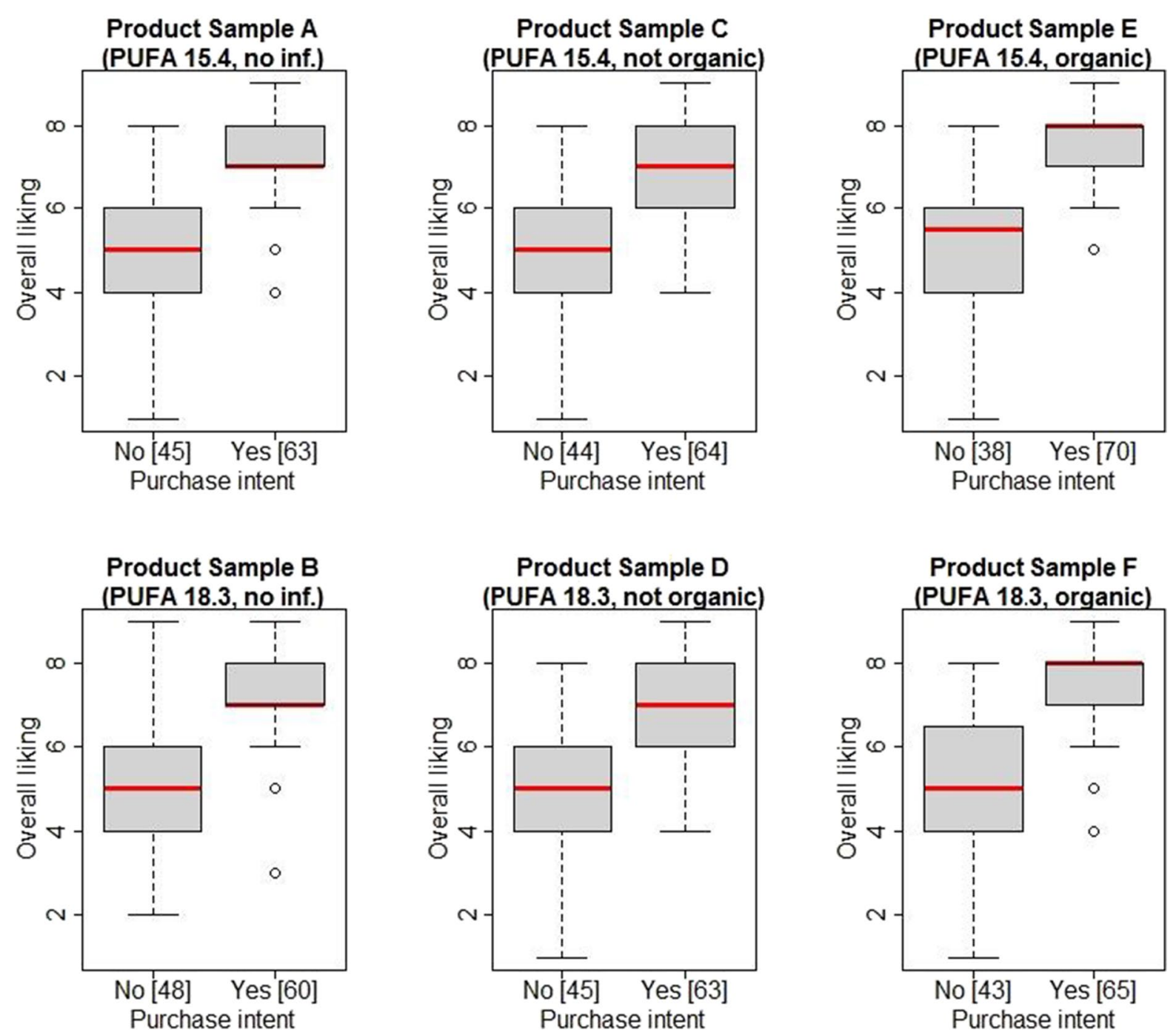

Fig. 1 Overall liking (scale from 1 to 9) by purchase intent. Distribution of overall liking for participants without (no) and with (yes) an intention to purchase product samples A through $\mathrm{F}$ 

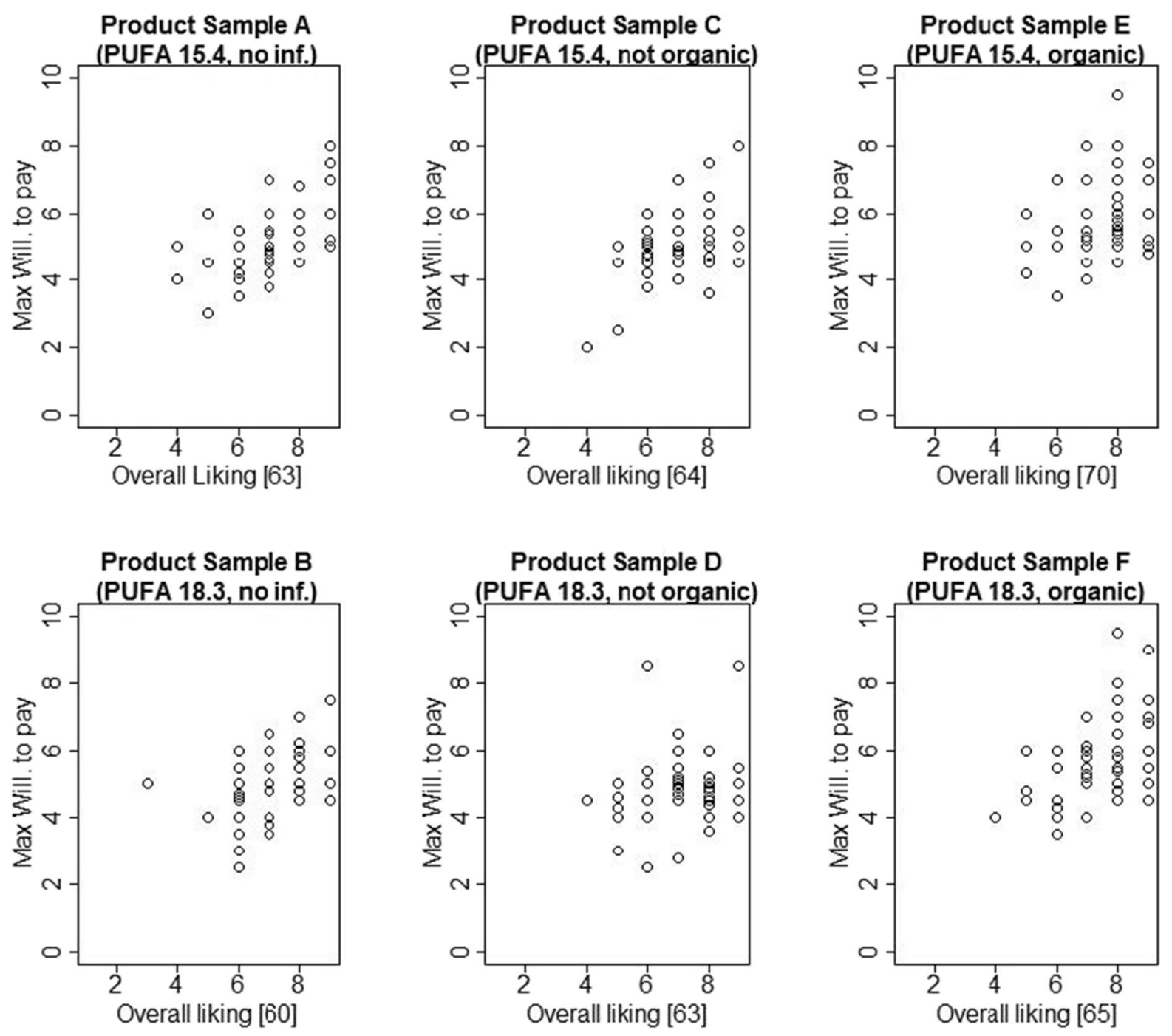

Fig. 2 Correlation between overall liking (scale from 1 to 9) and maximum willingness to pay in CHF (max will. to pay) 
Open Access This article is licensed under a Creative Commons Attribution 4.0 International License, which permits use, sharing, adaptation, distribution and reproduction in any medium or format, as long as you give appropriate credit to the original author(s) and the source, provide a link to the Creative Commons licence, and indicate if changes were made. The images or other third party material in this article are included in the article's Creative Commons licence, unless indicated otherwise in a credit line to the material. If material is not included in the article's Creative Commons licence and your intended use is not permitted by statutory regulation or exceeds the permitted use, you will need to obtain permission directly from the copyright holder. To view a copy of this licence, visit http://creativecommons.org/licenses/by/4.0/.

\section{References}

Aaslyng MD, Meinert L (2017) Meat flavour in pork and beefFrom animal to meal. Meat Sci 132:112-117

Agroscope (2016) Fütterungsempfehlungen für Schweine (Gelbes Buch). Access: https://www.agroscope.admin. ch/agroscope/de/home/services/dienste/futtermittel/fuett erungsempfehlungen-schweine.html. (Date of consultation: 12.07.2021).

Ahn DU, Lutz S, Sim JS (1996) Effects of dietary $\alpha$-linolenic acid on the fatty acid composition, storage stability and sensory characteristics of pork loin. Meat Sci 43(3-4):291-299

Alonso V, del Mar Campo M, Provincial L, Roncalés P, Beltrán JA (2010) Effect of protein level in commercial diets on pork meat quality. Meat Sci 85(1):7-14

Apaolaza V, Hartmann P, Echebarria C, Barrutia JM (2017) Organic label's halo effect on sensory and hedonic experience of wine: a pilot study. Journal of sensory studies 32(1):e12243

Asioli D, Varela P, Hersleth M, Almli VL, Olsen NV, Naes T (2017) A discussion of recent methodologies for combining sensory and extrinsic product properties in consumer studies. Food Qual Prefer 56:266-273

Baranek E (2007) Wer kauft Bio? Zielgruppenspezifische Motive für den Kauf von Biolebensmitteln. Verlag Dr Köster, Berlin

Bates D, Mächler M, Bolker B, Walker S (2015) Fitting linear mixed-effects models using lme4. J Stat Softw 67(1):1-48

Bee G, Kragten SA, Früh B, Girard M (2021) Impact of 100\% organic diets on pig performance, carcass composition and carcass nutrient deposition efficiency. Organic Agriculture 1:1-13

Bee G, Silacci P, Ampuero-Kragten S, Candek-Potokar M, Wealleans AL, Litten-Brown J, ... Mueller-Harvey I. (2017). Hydrolysable tannin-based diet rich in gallotannins has a minimal impact on pig performance but significantly reduces salivary and bulbourethral gland size. Animal 11(9):1617-1625

Boutrolle I, Arranz D, Rogeaux M, Delarue J (2005) Comparing central location test and home use test results: application of a new criterion. Food Qual Prefer 16(8):704-713

Brewer MS, Zhu LG, McKeith FK (2001) Marbling effects on quality characteristics of pork loin chops: consumer purchase intent, visual and sensory characteristics. Meat Sci 59(2):153-163

Bryhni EA, Byrne DV, Rødbotten M, Møller S, Claudi-Magnussen C, Karlsson A, ... Martens M (2003) Consumer and sensory investigations in relation to physical/chemical aspects of cooked pork in Scandinavia. Meat science 65(2):737-748

Bryhni EA, Hunt MC, Ofstad R (2002) Consumer discrimination of rancidity in pork loin chops and pork sausages. $\mathrm{J}$ Food Sci 67(9):3469-3475

Casal N, Font-i-Furnols M, Gispert M, Manteca X, Fàbrega E (2018) Effect of environmental enrichment and herbal compounds-supplemented diet on pig carcass, meat quality traits, and consumers' acceptability and preference. Animals 8(7):118

Christensen RHB (2015) Ordinal-regression models for ordinal data. R Package Version 28:2015

Combris P, Bazoche P, Giraud-Héraud E, Issanchou S (2009) Food choices: what do we learn from combining sensory and economic experiments? Food Qual Prefer 20(8):550-557

Cragg JG (1971) Some statistical models for limited dependent variables with application to the demand for durable goods. Econometr J Econometr Soc 39(5):829-844

Crowder MJ, Hand DJ (2017) Analysis of repeated measures. Routledge, Oxfordshire

Cudeck R (1996) Mixed-effects models in the study of individual differences with repeated measures data. Multivar Behav Res 31(3):371-403

Deliza R, MacFie HJ (1996) The generation of sensory expectation by external cues and its effect on sensory perception and hedonic ratings: a review. J Sens Stud 11(2):103-128

Dransfield E, Ngapo TM, Nielsen NA, Bredahl L, Sjödén PO, Magnusson M, ... Nute GR (2005) Consumer choice and suggested price for pork as influenced by its appearance, taste and information concerning country of origin and organic pig production. Meat science 69(1):61-70

EAER Ordinance on Organic Farming (2020) Transitional provisions to the Amendment of 31 October 2012, 910.181 C.F.R. $\S 6$

Fernqvist F, Ekelund L (2014) Credence and the effect on consumer liking of food-a review. Food Qual Prefer 32:340-353

Früh B (2016) Ermittlung und Optimierung der Fettqualität bei Bioschweinen. Unpublished report Forschungsinstitut für biologischen Landbau (FiBL)/Bio Suisse, Frick/Basel

Gläser KR, Wenk C, Scheeder MRL (2002) Effect of dietary mono- and polyunsaturated fatty acids on the fatty acid composition of pigs' adipose tissues. Arch Anim Nutr 56(1):51-65

Grunert KG, Bredahl L, Bruns $\varnothing$ K (2004) Consumer perception of meat quality and implications for product development in the meat sector-a review. Meat Sci 66(2):259-272

Hadorn R, Eberhard P, Guggisberg D, Piccinali P, Schlichtherle-Cerny $\mathrm{H}$ (2008) Effect of fat score on the quality of various meat products. Meat Sci 80(3):765-770

Hair JF, Anderson RE, Babin BJ, Black WC (2010) Multivariate data analysis: a global perspective, vol 7. Pearson Education, London 
Harper GC, Makatouni A (2002) Consumer perception of organic food production and farm animal welfare. British Food Journal 104(3/4/5):287-299

Hemmerling S, Obermowe T, Canavari M, Sidali KL, Stolz H, Spiller A (2013) Organic food labels as a signal of sensory quality-insights from a cross-cultural consumer survey. Org Agric 3(1):57-69

Hoek AC, Luning PA, Stafleu A, de Graaf C (2004) Foodrelated lifestyle and health attitudes of Dutch vegetarians, non-vegetarian consumers of meat substitutes, and meat consumers. Appetite 42(3):265-272

Houben JH, Krol B (1980) Acceptability and storage stability of pork products with increased levels of polyunsaturated fatty acids. Meat Sci 5(1):57-70

Hughner RS, McDonagh P, Prothero A, Shultz CJ, Stanton J (2007) Who are organic food consumers? A compilation and review of why people purchase organic food. J Consum Behav Int Res Rev 6(2-3):94-110

Hung Y, Verbeke W (2018) Sensory attributes shaping consumers' willingness-to-pay for newly developed processed meat products with natural compounds and a reduced level of nitrite. Food Qual Prefer 70:21-31

Iaccarino T, Di Monaco R, Mincione A, Cavella S, Masi P (2006) Influence of information on origin and technology on the consumer response: the case of soppressata salami. Food Qual Prefer 17(1-2):76-84

Kerth CR, Harbison AL, Smith SB, Miller RK (2015) Consumer sensory evaluation, fatty acid composition, and shelf-life of ground beef with subcutaneous fat trimmings from different carcass locations. Meat Sci 104:30-36

Kim SJ (2014) Herbal chrysanthemi flos, oxidative damage and protection against diabetic complications. Diabetes: oxidative stress and dietary antioxidants. pp 201-211

Kouba M, Enser M, Whittington FM, Nute GR, Wood JD (2003) Effect of a high-linolenic acid diet on lipogenic enzyme activities, fatty acid composition, and meat quality in the growing pig. J Anim Sci 81(8):1967-1979

Kuhnert H, Feindt PH, Wragge S, Beusmann V (2003) Nachfrage nach Öko-Lebensmitteln: Veränderung durch BSE? Ökologie \& Landbau Jahrbuch Öko-Landbau 125(1/2003):29-32

Lange C, Issanchou S, Combris P (2000) Expected versus experienced quality: trade-off with price. Food Qual Prefer 11(4):289-297

Lange C, Martin F, Chabanet C, Combris P, Issanchou S (2002) Impact of the information provided to consumers on their willingness to pay for Champagne: comparison with hedonic scores. Food Qual Prefer 13(7-8):597-608

Lange C, Rousseau F, Issanchou S (1998) Expectation, liking and purchase behaviour under economical constraint. Food Qual Prefer 10(1):31-39

Leiber F, and Früh B (2014) Aspekte zur Zulassung von Aminosäurepräparaten aus fermentativer Produktion in der Tierernährung im biologischen Landbau. Grundlagenpapier. Forschungsinstitut für biologischen Landbau. Frick. Access: https://www.betriebsmittelliste.ch/filea $\mathrm{dmin} / \mathrm{bml}$-ch/documents/stellungnahmen/Argumetari um_fermentierte_Aminosaeuren_Mai_2014.pdf (Date of consultation: 12.07.2021)
Lim J (2011) Hedonic scaling: a review of methods and theory. Food Qual Prefer 22(8):733-747

Lusk JL, Hudson D (2004) Willingness-to-pay estimates and their relevance to agribusiness decision making. Appl Econ Perspect Policy 26(2):152-169

Magnusson MK, Arvola A, Hursti UKK, Åberg L, Sjödén PO (2003) Choice of organic foods is related to perceived consequences for human health and to environmentally friendly behaviour. Appetite 40(2):109-117

Moloney AP, Mooney MT, Kerry JP, Troy DJ (2001) Producing tender and flavoursome beef with enhanced nutritional characteristics. Proc Nutr Soc 60(2):221-229. https://doi.org/10.1079/PNS200077

Moskowitz HR (1985) New directions for product testing and sensory analysis of foods. Food and Nutrition Press

Mueller S, Szolnoki G (2010) The relative influence of packaging, labelling, branding and sensory attributes on liking and purchase intent: Consumers differ in their responsiveness. Food Qual Prefer 21(7):774-783

Müller Richli M, Scheeder M (2014) Das Schwein ist, was es frisst. Neues Bewertungssystem für die Schweinefleischqualität in der Schweiz. Die Fleischwirtschaft 94(6):57-59

Napolitano F, Braghieri A, Piasentier E, Favotto S, Naspetti S, Zanoli R (2010) Effect of information about organic production on beef liking and consumer willingness to pay. Food Qual Prefer 21(2):207-212

Napolitano F, Castellini C, Naspetti S, Piasentier E, Girolami A, Braghieri A (2013) Consumer preference for chicken breast may be more affected by information on organic production than by product sensory properties. Poult Sci 92(3):820-826

Oehlert GW (2010) A first course in design and analysis of experiments. University of Minnesota, Minnesota

Peryam DR, Pilgrim FJ (1957) Hedonic scale method of measuring food preferences. Food Technol 11:9-14

Plaßmann S, and Hamm U (2009) Kaufbarriere Preis?-Analyse von Zahlungsbereitschaft und Kaufverhalten bei ÖkoLebensmitteln. Final report of BÖL-project 06OE119. Access: https://orgprints.org/id/eprint/15745/1/1574506OE119-uni_kassel-hamm-2009-kaufbarriere_preis.pdf (Date of consultation: 12.07.2021)

Proviande (2014) Faktenblatt Schweinefettqualität. Access: https://www.suisseporcs.ch/Portals/0/Dokumente/News/ Faktenblatt_d.pdf (Date of consultation: 12.07.2021)

Proviande. (2020). Absatz Wurstwaren im Detailhandel. (Unpublished dataset)

R Core Team (2019) R: A language and environment for statistical computing. R Foundation for Statistical Computing, Vienna

AV Resurreccion (1998) Consumer sensory testing for product development. Aspen Publishers, Frederick

Rosenvold K, Andersen HJ (2003) Factors of significance for pork quality: a review. Meat Sci 64(3):219-237

Scheeder M, and Müller Richli M (2014) Nachhaltige Sicherung der Fettqualität bei Mastschweinen. Final report. Access: https://www.suisseporcs.ch/Portals/0/ Dokumente/News/Abschlussbericht_\%20Fettqualitaet_ BLW_140210.pdf (Date of consultation: 12.07.2021)

Scheeder M, Gläser K, Schwörer D, Wenk C (1998) Oxidative stability and texture properties of fermented sausages produced from pork differing in fatty acid composition. Paper 
presented at the 44th International Congress of Meat Science and Technology, Barcelona

Scholderer J, Nielsen NA, Bredahl L, Claudi-Magnussen C, Lindahl G (2004) Organic pork: consumer quality perceptions. Project paper $(02 / 04)$

Schönet F, Tischendorf F, Kirchheim U, Reichardt W, Bargholz J (2002) Effects of high fat rapeseed press cake on growth, carcass, meat quality and body fat composition of leaner and fatter pig crossbreeds. Anim Sci 74(2):285-297

Schouteten JJ, Gellynck X, Slabbinck H (2019) Influence of organic labels on consumer's flavor perception and emotional profiling: comparison between a central location test and home-use-test. Food Res Int 116:1000-1009

Schumacher U, Fidelak C, Koopmann R, Weißmann F, Snigula J, Brüggemann R, . . . Bender S (2011) Wissenstandsanalyse zur Tiergesundheit aller Nutztierarten im Ökologischen Landbau und 100\% Biofütterung. Final report. Bundesprogramm Ökologischer Landbau und andere Formen nachhaltiger Landwirtschaft, Bonn. Access: https:// orgprints.org/id/eprint/25088/1/25088-10OE088-biolandschumacher-2011-wissenstandanalyse-tiergesundheit.pdf (Date of consultation: 12.07.2021)

Soladoye PO, Shand PJ, Aalhus JL, Gariépy C, Juárez M (2015) Pork belly quality, bacon properties and recent consumer trends. Can J Anim Sci 95(3):325-340. https:// doi.org/10.4141/cjas-2014-121

Stewart JW, Kaplan ML, Beitz DC (2001) Pork with a high content of polyunsaturated fatty acids lowers LDL cholesterol in women. Am J Clin Nutr 74(2):179-187

Stoll P (2004) Ungesättigte Fettsäuren in Der Mastschweinefütterung Agrarforschung 11(6):242-245

Stoll P (2016) Fütterungsempfehlung Fettqualität beim Schwein. ETH-Schriftenreihe zur Tierernährung, 39, 200202. Access: https://ira.agroscope.ch/en-US/Page/Publi kation? einzelpublikationId $=36723 \&$ parentUrl $=\% 2$ FenUS\%2FPage\%2FPublikationsliste\%2FIndexMitarbeiter\% 3FagroscopeId\%3D4603\%26page\%3D2 (Date of consultation: 12.07.2021)

Stolz H, Bodini A, Stolze M, Hamm U, Richter T (2009) Lebensmittelqualität aus der Verbraucherperspektive: eine Synthese qualitativer Studien zur Wahrnehmung und Beurteilung verschiedener Qualitätskriterien bei ÖkoProdukten. Berichte Über Landwirtschaft: Zeitschrift Für Agrarpolitik Und Landwirtschaft 87(1):153-182

Stolz H, Stolze M, Janssen M, Hamm U (2011) Preferences and determinants for organic, conventional and conventionalplus products-the case of occasional organic consumers. Food Qual Prefer 22(8):772-779

Teuber R, Dolgopolova I, Nordström J (2016) Some like it organic, some like it purple and some like it ancient: consumer preferences and WTP for value-added attributes in whole grain bread. Food Qual Prefer 52:244-254
Torquati B, Tempesta T, Vecchiato D, Venanzi S (2018) Tasty or sustainable? The effect of product sensory experience on a sustainable new food product: an application of discrete choice experiments on Chianina tinned beef. Sustainability 10(8):2795

Van Lunen TA, Hurnik D, Jebelian V (2003) Growth performance, carcass quality, meat quality and fatty acid composition of pigs fed diets. Can J Anim Sci 83(1):45-52

Verbeke W, Van Oeckel MJ, Warnants N, Viaene J, Boucqué CV (1999) Consumer perception, facts and possibilities to improve acceptability of health and sensory characteristics of pork. Meat Science 53(2):77-99

VERBI Software (2019) MAXQDA 2020 [computer software]. Berlin, Germany: VERBI Software. Available from maxqda.com

Wang C, Qin N, Zhu M, Chen M, Xie K, Cheng Y, Shen H (2017) Metabolome-wide association study identified the association between a circulating polyunsaturated fatty acids variant rs174548 and lung cancer. Carcinogenesis 38(11):1147-1154

Warnants N, Van Oeckel MJ, Boucqué CV (1998) Effect of incorporation of dietary polyunsaturated fatty acids in pork backfat on the quality of salami. Meat Sci 49(4):435-445

Wenk C, Häuser A, Vogg-Perret D, Prabucki AL (1990) Einfluss mehrfach ungesättigter Fettsäuren im Futter auf die Qualität von Schweinefleisch. Fat Sci Tech 92(13):552-556

Witten S, Paulsen HM, Weißmann F, and Bussemas R (2014). Praxisbefragung zur Aminosäurelücke und praktische Möglichkeiten zur Verbesserung der Eiweißversorgung der Monogastrier in der Fütterung im Ökologischen Landbau. Thünen Working Paper. Johann Heinrich von Thünen-Institut. Braunschweig. Access: https://literatur. thuenen.de/digbib_extern/bitv/dn053521.pdf (Date of consultation: 12.07.2021)

Wood JD (1984) Fat deposition and the quality of fat tissue in meat animals. Butterworths, London

Wood JD, Enser M, Fisher AV, Nute GR, Sheard PR, Richardson RI, ... Whittington FM (2008) Fat deposition, fatty acid composition and meat quality: a review. Meat Sci 78:343-358

Wood JD, Richardson RI, Nute GR, Fisher AV, Campo MM, Kasapidou E, ... Enser M (2003) Effects of fatty acids on meat quality: a review. Meat Sci 66:21-32

Publisher's note Springer Nature remains neutral with regard to jurisdictional claims in published maps and institutional affiliations. 